Volume 9, No.5, September - October 2020

International Journal of Advanced Trends in Computer Science and Engineering

Available Online at http://www.warse.org/IJATCSE/static/pdf/file/ijatcse138952020.pdf

https://doi.org/10.30534/ijatcse/2020/138952020

\title{
Systematization of Measures on Lightning Protection of the Objects of Telecommunications Network
}

\author{
P. Anakhov ${ }^{1}$, A. Makarenko ${ }^{2}$, V. Zhebka ${ }^{3}$, V. Vasylenko ${ }^{4}$, M. Stepanov ${ }^{5}$ \\ ${ }^{1}$ Department of Infrastructure Systems, National power company "Ukrenergo", Kyiv, Ukraine, anakhov@i.ua \\ ${ }^{2}$ Department of Mobile and Video Information technologies, State University of Telecommunications, Kyiv, \\ Ukraine, makarenkoa@ukr.net \\ ${ }^{3}$ Department of Telecommunication Systems and Networks, State University of Telecommunications, Kyiv, \\ Ukraine, viktoria_zhebka@ukr.net \\ ${ }^{4}$ Department of Computer Science, State University of Telecommunications, Kyiv, Ukraine, \\ oknelisavvova172@gmail.com \\ ${ }^{5}$ Department of radio reception and signal processing, National technical University of Ukraine "Igor Sikorsky \\ Kyiv Polytechnic University", Kyiv, Ukraine, 2m.stepanov@gmail.com
}

\begin{abstract}
Damage to critical telecommunications systems by lightning strikes can lead to big casualty. The analysis of literature data has showed that high-altitude telecommunication masts, as well as air and underground line-cable structures are hit.

The purpose of the work is to optimize the measures taken to protect the objects of the telecom network from lightning strikes. The method of optimization of the measures includes assessment of the possibility of damage to the objects of the telecommunications network and their analysis, development and systematization of appropriate countermeasures.

The list of 11 striking factors of direct lightning strike and secondary effect of lightning activity has been determined; the result of their activity has been presented. A generalized scheme for the application of lightning protection measures has been developed. It includes short-term hazard forecasting and warning, and lightning-fast construction. Long-term measures include the use of lightning-resistant materials and structures and lightning protection systems, reconfiguration of the telecommunications system.

The concept of reasonable sufficiency should be used as a basic criterion in the development of a telecommunications network protection project. It means that in the conditions of the expected impact ensure the necessary requirements for electromagnetic compatibility, functional and information security of electronic systems with the minimum use of funds and protection measures. To ensure the reliability of the objects of protection, the best solution from an economic point of view, is the zone concept, which does not contradict the generally accepted rules of lightning protection of the telecommunications network objects. A hybrid telecommunications network meets these requirements by proposing the separation of communication channels by transmission media. The selection of the network segments by the nature of the transmitted signal allows avoiding the action
\end{abstract}

of such direct lightning strikes and secondary effect of lightning activity that do not physically affect them.

Key words : damaging factor, secondary effect of lightning activity, lightning activity, zone construct, direct lightning strike.

\section{INTRODUCTION}

In the recent decades, the number of natural disasters caused by climate changings on Earth has been growing worldwide. It is believed that global warming, in particular, contributes to an increase in the number of lightning strikes. It is forseen of their systematically increasing by $12 \pm 5 \%$ with an increase in average temperature for each Celsius degree and by about $50 \%$ during the XXI century [1].

According to another prognosis, the number of lightning strikes by 2100 should decrease by $15 \%$ compared to the current [2].

In any events, lightning strikes are not canceled and in many cases do not go unnoticed. The comparatively low frequency of thunderstorms and the inaccuracy of lightning strike coordinates cannot be a reason to ignore the danger of this natural disaster. Accurate hits to critical information and telecommunication systems turn into major accidents, for example, [3-8].

The taken measures are insufficient or ineffective. The variability of both natural and anthropogenic environments requires a reassessment of current and future situations.

\section{LITERATURE DATA ANALYSIS AND PROBLEM STATEMENT}

In work [9] it has been shown that lightning most often strikes tall buildings, especially those that dominate the surrounding area. On the plain, most strikes fall on individual masts, towers, chimneys, and so on. In mountainous areas, low-rise buildings often suffer if they stand on separate high hills or on 
the top of a mountain. The explanation is simple: an electric discharge, which is lightning, is easier to cover a shorter distance from the hypocenter (lightning core) to an elevated object. Thus, there is 0.1 of lightning strike per year in a mast of 30 metres high, on average in Europe, while for a separate object with a height of 100 metres there are almost 10 times more.

It is also known that lightning often strikes open air lines [9, 10]. It is determined that in areas with lightning activity is 20-25 days per year, during the thunderstorm period for every $100 \mathrm{~km}$ of the route there are $8-10$ incidents of direct lightning strike in the communication line [10].

There are data on lightning damage to underground communication cables $[9,10]$. According to the research presented in the article [11]:

- between the cities of Kansas City and Dallas (USA), where the lightning activity is 50 days a year, in 15 years of observations, accidents have occurred approximately 0.5 times/year for every 100 miles of the route ( 0.8 incidents per $100 \mathrm{~km})$;

- between the cities of Atlanta and Macon (USA), where the lightning activity is 70 days a year, for 3 years of observations of the accident occurred approximately 20 times / year for every 100 miles of the route ( 32 incidents per $100 \mathrm{~km}$ ).

To reduce the risk of lightning strikes, forecasting and warning of danger are used [12-14], lightning protection systems are installed [15-18], and lightning-resistant materials are used $[10,19]$.

General principles of lightning protection of buildings, structures and their parts, utilities also imply their division into zones [20-23]. This structure has modern telecommunications hybrid networks, in which communication lines are divided by the transmission medium, the physical domain of the transmitted signal, frequency and time [24-28].

Building of the optimal lightning-protected telecommunications network requires a systematic approach when choosing protection methods. It allows to claim that it is appropriate to conduct a study on the systematization of measures for lightning protection of telecommunications networks.

\section{PURPOSE AND RESEARCH OBJECTIVES}

The purpose of the work is to optimize measures of reducing the losses from lightning strikes of the telecommunications network.

To achieve this goal it is necessary to solve the following tasks:

- to analyze the effect of lightning on the telecommunications network;

- to systematize countermeasures.

\section{METHOD OF OPTIMIZATION OF MEASURES FOR PROTECTION OF TELECOMMUNICATIONS NETWORK FROM THE CONSEQUENCES OF LIGHTNING}

The research material is a natural and anthropogenic environment, which is exposed to lightning strikes.

The method of achieving this goal is technology, which must be completed with sound proposals of protection the telecommunications network from lightning strikes.

The method of optimization of measures for protection of a telecommunications network from consequences of action of any natural disasters has been developed. It includes the staged collection of information about their impact on the resources of the telecommunications network, analysis of actions, and the development of appropriate countermeasures [28]. The universality of this method has allowed adopting it for the development of measures for protection of the telecommunications network from one of the most common and unprofitable natural disasters - lightning strikes. An additional task of the method is the systematization of the measures for lightning protection of the telecommunications network objects.

\section{DEVELOPMENT OF THE LIGHTNING PROTECTION MEASURES}

\subsection{StageAnalysis of the Lightning Strikes Influence on the Functioning of the Objects}

The standard [29] about the dangerous natural phenomenon "thunderstorm"defines a single electrophysical damaging factor, the nature of its action and manifestation is an electric lightning discharge, and the result - the destruction of the objects.

The following lightning-related accidents have been noted in the studies:

- fires in natural ecological systems [5];

- fires at oil refineries and petrochemical enterprises [6];

- fires at ammunition storage bases [7, 8];

- thermal destruction of electrical and radio elements, electrical conductors $[9,10,27]$;

- mechanical connection failure [9, 27];

- induced distortions of transmitted information [15, 27, 30-32].

From the perspective of intensity of lightning influence it has been distinguished direct (direct), or indirect (close) strikes and distant discharges. On direct lightning strike, lightning strikes the lightning rod of the protected objects [9, 27]. The list of damaging factors of lightning strike and the result of their action are given in table 1 .

Table 1: Attributes of Cleveland dataset

\begin{tabular}{|l|l|}
\hline \multicolumn{1}{|c|}{$\begin{array}{c}\text { Damaging } \\
\text { factors (DF) }\end{array}$} & \multicolumn{1}{c|}{ The result of DF action } \\
\hline 1. Dangerous impact of direct lightning strike: \\
\hline $\begin{array}{l}\text { 1.1. Electric } \\
\text { lightning }\end{array}$ & $\begin{array}{l}\text { The potential for remote land increases } \\
\text { (see Fig. 1, a). At } I_{\max }=200 \mathrm{kA} \text { and }\end{array}$ \\
\hline
\end{tabular}




\begin{tabular}{|c|c|}
\hline $\begin{array}{l}\text { discharge [9], } \\
\text { including: }\end{array}$ & $\begin{array}{l}R_{E}=5 \mathrm{Om} U_{\max }=1 \mathrm{mB} \text { (statistical value of } \\
\text { the maximum amperage } I_{\max }=2-200 \mathrm{kA} \text { ) } \\
\text { [27]. Lightning current passes through the } \\
\text { conductive structures of the affected } \\
\text { object, there are dangerous voltage } \\
\text { increases (overvoltage of direct lightning } \\
\text { strike) [9] }\end{array}$ \\
\hline $\begin{array}{l}\text { - breakthrough of } \\
\text { lightning current } \\
\text { through a sliding } \\
\text { spark channel: a) } \\
\text { along the soil } \\
\text { surface }[9] ; \text { b) on } \\
\text { the roots of the } \\
\text { trees }[9,10,33]\end{array}$ & $\begin{array}{l}\text { Damaging the underground } \\
\text { communications, cables, the object's } \\
\text { grounding conductor protectedwith } \\
\text { lightning rod [9] }\end{array}$ \\
\hline $\begin{array}{l}\text { - introduction of } \\
\text { the high potential } \\
\text { into underground } \\
\text { and ground metal } \\
\text { communications, } \\
\text { which are } \\
\text { included in the } \\
\text { protected } \\
\text { structure [9] }\end{array}$ & $\begin{array}{l}\text { Spark breakdown of lightning between } \\
\text { communication and nearby structural } \\
\text { element [9] }\end{array}$ \\
\hline $\begin{array}{l}\text { 1.2. Thermal } \\
\text { action of plasma } \\
\text { (hot) channel [9] }\end{array}$ & $\begin{array}{l}\text { 1. It may cause fire in contact with } \\
\text { combustible materials [9] } \\
\text { 2. In contact with non-combustible } \\
\text { materials it may cause damage to the } \\
\text { elements: a) thermal destruction of } \\
\text { miniature antennas and sensors, placed on } \\
\text { the external structures of the object [9]; b) } \\
\text { overheating of the conductors through } \\
\text { which the lightning current flows [27]; c) } \\
\text { local overheating of metal elements, under } \\
\text { the long action of which their temperature } \\
\text { can rise to 700-1000 }{ }^{\circ} \mathrm{C} \text { and provoke a fire } \\
\text { or mechanical connection failure of fixed } \\
\text { (welded, bolted, riveted) and movable } \\
\text { joints [9]; at } \int I d t=300 \text { Kл, aluminum } \\
\text { walls up to } 5 \text { mm thick melt (statistical } \\
\text { value of the charge } \int I d t=150-300 \text { Кl) } \\
\text { [27]; d) penetration and burning-up of the } \\
\text { elements [9]. The lead covering of the } \\
\text { underground cable often melts, the jute } \\
\text { braid burns, the insulation burns, the cable } \\
\text { cores melt, and linear insulators break } \\
\text { through. From the pressure of soil moisture } \\
\text { vapors and gases arising from the } \\
\text { combustion of the jute braid, dents are } \\
\text { formed on the cable covering and its } \\
\text { deflections, breaks in the tape armor [10] }\end{array}$ \\
\hline \multicolumn{2}{|c|}{$\begin{array}{l}\text { 2. Dangerous impacts of the secondary effect of lightning } \\
\text { activity: }\end{array}$} \\
\hline $\begin{array}{l}\text { 2.1. Induced } \\
\text { overvoltage on } \\
\text { electrical circuits } \\
{[9,20]}\end{array}$ & $\begin{array}{l}\text { 1. At } d I / d t=200 \mathrm{kA} / \mathrm{mcs} \text { and } l_{1}=10 \mathrm{M} \text {, } \\
l_{2}=0.1(10) \mathrm{m} \text { the voltage values are } \\
u_{i}=40 \mathrm{~B}(216 \mathrm{kB}) \text { (statistical value of the } \\
\text { rate of increase of current } \\
d I / d t=2-200 \mathrm{kA} / \mathrm{mcs}) \text {, see Fig. } 1, b\end{array}$ \\
\hline
\end{tabular}

[27]. In periods when the instantaneous value of the signal-to-noise ratio (where noise is the value of the induced voltage) exceeds the allowable level - reducing noise immunity, increasing the probability of transmission errors [15, 30-32]

2. The conductors through which the lightning current flows are heated. At $\int I^{2} d t=10 \mathrm{MJ} / \mathrm{Om}$, copper wires with a cross section of $10 \mathrm{~mm}^{2}$ and steel wires with a cross section of $25 \mathrm{~mm}^{2}$ melt (statistical value of the lightning strike integral is $\int I^{2} d t=2,5-10 \mathrm{MJ} / \Omega$ ) [27]

3. Insulation of conductors of current-carrying wires breaks through $[9$, 10]

2.2. Electrostatic The formation of a charge that can cause a induction on the spark breakdown at the site of poor contact grounded [9]

conductors or metal objects [9]

Fig. 1 shows the results of lightning action when stricking to a lightning rod.
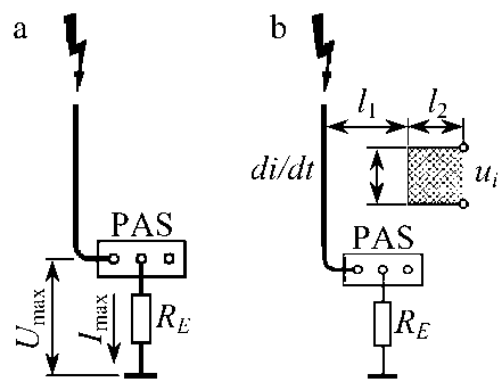

Figure 1: Lightning action when stricking to a lightning rod [27]

For more details of the results of lightning activity see table 1.

\subsection{Synthesis of Measures to Protect Objects From Lightning Activity}

It must be admitted that natural disasters are in many cases inevitable. Thus, the optimization of their negative consequences becomes a practical task. Reducing the risk of lightning strikes (lightning protection measures) may include: short-term prognostification and notification of the danger of strikes; long-term prognostification and establishment of a strict order of building codes in high-risk areas. The scheme of application of lightning protection measures is shown in fig. 2.

There are about 1.5 thousand thunderstorms at the same time on Earth, the average intensity of the discharges is estimated at 46 lightning per second [12]. Climate change has caused a surge of interest in the study of the dynamics of thunderstorm activity $[1,2]$. The practical benefit of forecasts is timely preparation for dangerous events that turn into major accidents [3-8]. Synoptic and climatic researches, numerical modeling are used for forecasting [12-14]. 
For the manufacture of telecommunications equipment and lightning protection elements materials resistant to thermal and dynamic influences are being used, basing on the results of the damaging factor of lightning strikes [19]. In the areas of high lightning activity, the lightning-resistant cables with high conductivity of the sheath (aluminum) and high electrical insulation strength is proposed to be used [10]. To protect information from transmission errors, noise-tolerant coding with error detection and error correction is used [31].

\begin{tabular}{|c|c|c|c|c|c|}
\hline \multicolumn{6}{|c|}{ Prognostification the danger of lightning strikes } \\
\hline$\forall$ & \multicolumn{5}{|c|}{$\downarrow$} \\
\hline \multirow{2}{*}{$\begin{array}{l}\text { Short- } \\
\text { term }\end{array}$} & \multicolumn{5}{|c|}{ Long-term } \\
\hline & \multicolumn{5}{|c|}{$\downarrow$} \\
\hline$\bigvee$ & \multicolumn{5}{|c|}{ Lightning fast construction } \\
\hline \multirow{4}{*}{$\begin{array}{l}\text { Noti- } \\
\text { fica- } \\
\text { tion }\end{array}$} & \multirow{4}{*}{\begin{tabular}{|c|}
\multicolumn{1}{c}{} \\
Applica- \\
tion of \\
light- \\
ning- \\
resistant \\
materi- \\
als and \\
struc-
\end{tabular}} & \multicolumn{2}{|c|}{$\downarrow$} & \multicolumn{2}{|c|}{$\downarrow$} \\
\hline & & \multicolumn{2}{|c|}{$\begin{array}{l}\text { Strike inter- } \\
\text { ception }\end{array}$} & \multicolumn{2}{|c|}{$\begin{array}{l}\text { Removal from the } \\
\text { strike }\end{array}$} \\
\hline & & 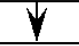 & $\downarrow$ & 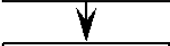 & $\downarrow$ \\
\hline & & $\begin{array}{l}\text { Pas- } \\
\text { sive }\end{array}$ & Active & \begin{tabular}{|} 
Reconfigu- \\
ration of \\
the power \\
system
\end{tabular} & $\begin{array}{l}\text { Reconfig- } \\
\text { uration of } \\
\text { the trans- } \\
\text { mission } \\
\text { network }\end{array}$ \\
\hline
\end{tabular}

Figure 2: Generalized scheme of application of lightning protection measures

The traditional means of counteracting the damaging factors of thunderstorms is a "passive" lightning protection system, which consists of a lightning conductor (lightning rod, current collector), grounding, equipotential bonding system (PAS), and surge protection devices $[15,16]$.

The main difference of so-called "active" lightning protection from passive lightning protection devices is the presence of an active lightning rod, which responds to the increase in electromagnetic field strength that occurs when approaching the storm front [17].

- The principle of operation of the ESE (Early Strimmer Emission) lightning rods is based on the use of advanced emission. The basis of application is an active head with an electronic unit, which in the pre-thunderstorm period for a fraction of a second before the lightning discharge produces high-frequency pulses. As a result, a corona discharge occurs on the lightning rod, which forms a counter ionizing channel for the lightning discharge on the lightning rod.

- The principle of operation of the CTS (Charge Transfer System) lightning rods is to remove the high voltage electric field near the earth's surface during the formation of a thunderstorm. This is done to prevent conditions, which can cause the formation of lightning.

- The operation of the DAS (Dissipation Array System) is based on the phenomenon of corona development from sharply protruding structures that are in a strong electric field of a storm cloud. DAS is a metal hemispherical structure of the "umbrella" type, on which are distributed 5-10 thousand metal needles with a height of about $10 \mathrm{~cm}$. Each of the needles ionizes the air above the "umbrella", minimizing the possibility of forming a counter leader. Thus, DAS does not intercept the lightning discharge, but prevents its occurrence. There is an opinion about the incapacity of active lightning protection [18]. It is believed that there are no devices and methods that can change natural weather phenomena to such an extent as to prevent lightning strikes [15].

It is fair to say that many regions of the world use artificial regulation of precipitation, and since then their sources, lightning-hazardous clouds. These are works to increase the amount of precipitation for the needs of agriculture and the creation of water reserves in reservoirs in different countries: Honduras in 1993-1997, Turkey in 1992, China in 1998, the United States in 1989-2000, and Greece in 1992-1993 [34].

There were works carried out to reduce rainfall during meteorological protection in Moscow, St. Petersburg, Rostov-on-Don, Tashkent, and Astana [35]. It should be added that on December 10, 1976, the UN Assembly Resolution №31/72, the Convention on the Prohibition of Military or Any Other Enemy Use of Means of Environmental Impact had been adopted. The term "means of environmental impact" refers to any means to change it by deliberate management of natural processes [36].

According to the accepted standards the general principles of protection of objects against a lightning mean their division into zones. Such objects include buildings, structures and their parts, including the people who are in them, engineering networks belonging to the building (structure), etc. [20-23].

During the transition from one zone to another, the limitations of the peak values of overvoltages that occur in low-voltage installations and electromagnetic field pulses change. $O_{A}$ and $O_{B}$ are marked in the accepted designations of the zone with the greatest risk. The following zones are indicated by the corresponding numbers $(1,2,3, \ldots)$. The higher the zone number, the lower the value of the permissible levels of impulse interference. General principles of division of the object into zones and locations of the elements and protective devices are shown in Fig. 3, 4.

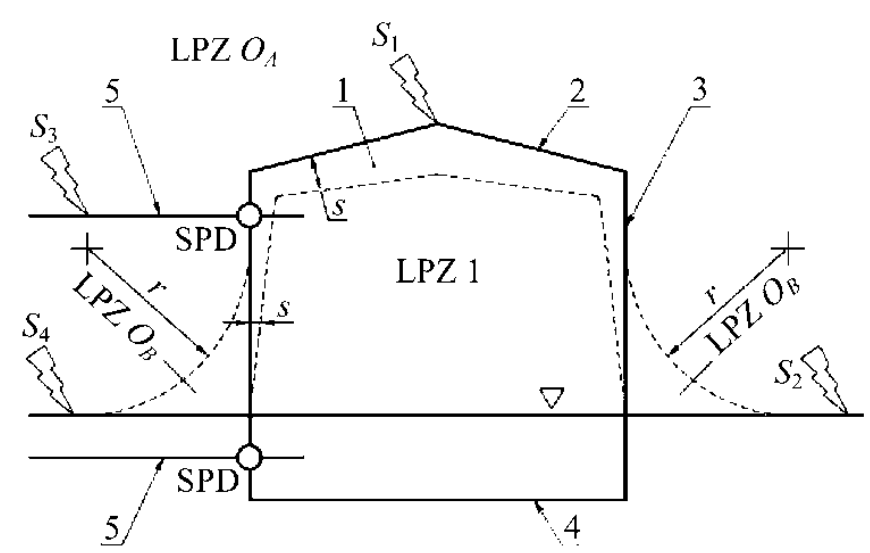

Figure 3: General principles of the object into zones division and locations of the elements and protective devices: lightning protection zones, defined in accordance with the lightning protection system

[21] 
The following designations have been accepted in fig. 3 . Lightning Protection Zones (LPZ), defined in accordance with the lightning protection system (LPS): 1 - building (structure); S1 - lightning strike in the building (structure); $2-$ lightning rod system; S2 - lightning strike near the building (structure); 3 - current drain system; S3 - lightning strike in the line of communications of the building (structure); 4 grounding system; S4 - lightning strike near the communication lines of the building (structure); 5 - incoming communications; $r$ is the radius of the fictitious sphere; $s$ is the safe distance when sparking; $\nabla$ - ground level; $O_{-}$ equipotential bonding system through the use of surge protection devices; LPZ $O_{A}$ - direct lightning strike, full lightning current; LPZ $O_{B}-$ no direct lightning strike, partial lightning current or induced current; LPZ 1 - no direct lightning strike, partial lightning current or induced current; the protected volume inside LPZ 1 must take into account the distance $s$.

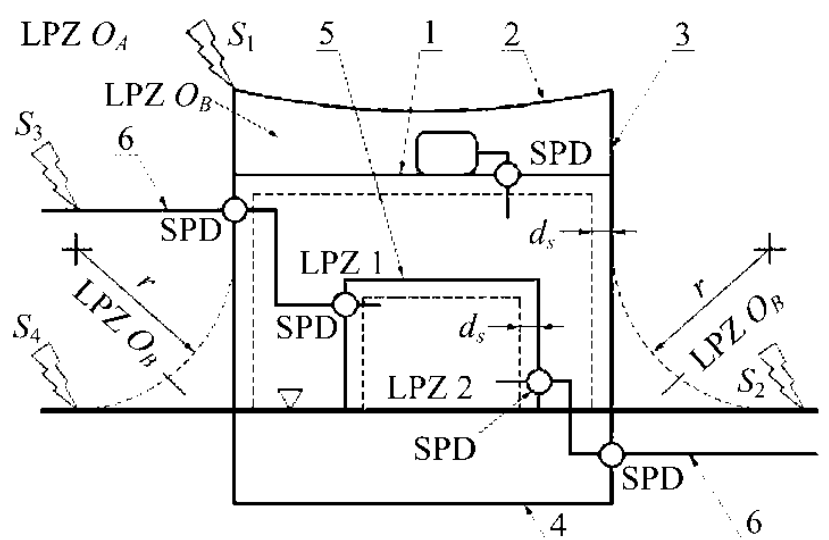

Figure 4: General principles of division of the object into zones and locations of elements and protective devices: lightning protection zones, defined in accordance with the system of surge protection [21]

The following designations have been accepted in fig. 4. LPZ lightning protection zones, defined in accordance with the Surge Protection Measures (SPM) system: 1 - building (structure) (LPZ screen 1); $S_{1}$ - lightning strike in the building (structure); 2 - lightning rod system; $S_{2}$ - lightning strike near the building (structure); 3 -drain system; $S_{3}$ - lightning strike in the line of communications of the building (structure); 4 grounding system; $S_{4}-$ lightning strike near the communication lines of the building (structure); 5 - room (LPZ screen 2); $r$ is the radius of the fictitious sphere; 6 communications of the building (structure); $d_{s}-$ safe distance from the magnetic field; $\nabla$ - ground level; $O$ - equipotential bonding system through the use of surge protection devices; LPZ $O_{A}$ - direct lightning strike, full lightning current, full magnetic field; LPZ $O_{B}-$ no direct lightning strike, partial lightning current or induced current, the action of a full magnetic field; LPZ 1 - no direct lightning strike, partial lightning current or induced current, the action of a weaker magnetic field; LPZ 2 - no direct lightning strike, partial lightning current or induced current, the action of an even weaker magnetic field; in the protected volume inside LPZ 1 and LPZ 2 it is necessary to keep a safe distance $d_{s}$. The $O_{A}$ zone is the zone of the external environment of the object, all points of which may be directly struck by lightning and the impact of the electromagnetic field that occurs. The $O_{B}$ zone is the zone of the external environment of the object, the points of which are not directly struck by lightning, because they are in a space protected by an external lightning protection system. However, a full electromagnetic field operates in this zone. Zone 1 - the inner zone of the object, the points of which are not directly struck by lightning. In this zone, the currents in all conductive parts are much less important compared to zones $O_{A}$ and $O_{B}$. The electromagnetic field is also reduced comparing to the $O_{A}$ and $O_{B}$ zones due to the shielding properties of building structures. Other zones (2, 3 , etc.) are established in case the further reduction of current and/or weakening of an electromagnetic field is necessary. The requirements for the parameters of the zones are determined in accordance with the requirements for the protection of different zones of the object. As the number of the protection zone increases, the level of influence of the electromagnetic field and the corresponding value of the possible lightning current decrease. At the boundary of the separate zones it is necessary to provide a protective series connection of all metal parts to equalize the protective potential with the provision of periodic monitoring.

Lightning is the main cause of power transmission and distribution system failures in many parts of the world. In the United States alone, lightning damages more than $\$ 1$ billion annually. Therefore, it is proposed, as far as possible, to eliminate or minimize the linking of the communication infrastructure to the grid infrastructure. This will provide reserve power due to diesel generators, autonomous wind and solar power plants [24, 38].

According to existing experience, reconfiguration of the telecommunications network is performed in case the use of excessive resources. It is proposed to apply the redundancy of communication lines by dividing the communication channels by environments - in free space, on artificial guides (for example, on cable lines of transport network and wireless lines of network WiMAX [39]). It is also proposed to use line redundancy due to the separation of physical domain of signals (for example, when using wired communication lines of access networks and lines of optical wireless transmission technology VLC [40], when using FSO/RF wireless hybrid transmission lines [26]). There are proposals for redundancy of communication lines by combining existing wired and wireless networks into a single hybrid (heterogeneous) network [41]. Such networks are characterized by an increased coefficient of readiness of telecommunication channels, as shown in the article [28].

\section{DISCUSSION OF THE RESULTS OF THE DEVELOPMENT OF LIGHTNING PROTECTION MEASURES}

Analysis of the impact of lightning strikes on the functioning of network facilities and the synthesis of protection measures 
has become the basis for the construction of a generalized scheme for the application of lightning protection measures. Systematization of the measures for lightning protection, in turn, is a part of the work to optimize the lightning protection system of telecommunications networks.

The study has not showed that the discharge channel energy, which is approximately $10^{6} \mathrm{~J}$ [27], causes weak "subtle effects" on the environment, which are usually not taken into account when developing measures to reduce lightning damage. Their list and result of activity are given in table 2 .

Table 2: Damaging factors of lightning strike and the result of their activity

\begin{tabular}{|c|c|}
\hline $\begin{array}{c}\text { Damaging } \\
\text { factors (DF) }\end{array}$ & The result of DF activity \\
\hline \multicolumn{2}{|c|}{ 1. Dangerous effects of direct lightning strike: } \\
\hline $\begin{array}{l}1.3 \text {. Light } \\
\text { radiation [27] }\end{array}$ & $\begin{array}{l}\text { Depending on the intensity of the light flux } \\
\text { and the properties of the materials, it can } \\
\text { cause charring, melting and ignition, } \\
\text { leading to fires [42]. }\end{array}$ \\
\hline $\begin{array}{l}\text { 1.4. Acoustic } \\
\text { impact on the } \\
\text { environment } \\
\text { (thunder) [27] }\end{array}$ & $\begin{array}{l}\text { Fractures, deformations of the structures, } \\
\text { ruptures of gas pipelines holding } \\
\text { communication cables under excess } \\
\text { pressure and ruptures of cables [43] }\end{array}$ \\
\hline $\begin{array}{l}\text { 1.5. X-ray and } \\
\gamma \text {-radiation }[44]\end{array}$ & $\begin{array}{l}\text { 1. Fiber degradation, which means the } \\
\text { violation of its structure and changes in } \\
\text { micro- and macroscopic properties[45] } \\
\text { 2. Distortion of information transmitted } \\
\text { over the optical cable [32] } \\
\text { 3. Reducing the intensity of the light } \\
\text { emitted by the LED, as well as reducing the } \\
\text { sensitivity of the photodetector receiving } \\
\text { the light signal. Together, these two effects } \\
\text { lead to a total decrease of the signal } \\
\text { transmitted over the fiber-optic } \\
\text { communication line. At fast neutron fluxes } \\
\text { up to } 10^{12} \mathrm{n} / \mathrm{cm}^{2} \text { the semiconductor } \\
\text { elements retain their efficiency, at fluxes of } \\
\sim 5 \times 10^{14} \mathrm{n} / \mathrm{cm}^{2} \text { they completely fail [46] }\end{array}$ \\
\hline \multicolumn{2}{|c|}{ 2. Dangerous effects of secondary effect of lightning activity: } \\
\hline $\begin{array}{l}2.3 . \\
\text { Electrodynamic } \\
\text { action of } \\
\text { lightning current } \\
\text { [9] }\end{array}$ & $\begin{array}{l}\text { Mechanical deformations of thin-walled } \\
\text { surfaces of the structures [9] }\end{array}$ \\
\hline $\begin{array}{l}2.4 . \\
\text { Electrohydraulic } \\
\text { action of } \\
\text { lightning current } \\
\text { [9] }\end{array}$ & $\begin{array}{l}\text { Evaporation, decomposition, gas } \\
\text { generation of composite materials [9] }\end{array}$ \\
\hline
\end{tabular}

Exposing the subtle effects of damaging factors of lightning requires the development of appropriate countermeasures. Possible precautionary measures to reduce losses are developed according to the generalized scheme of fig. 2 . The scheme is universal and suitable for use in the development of lightning protection of arbitrary objects.

The concept of reasonable sufficiency should be used as a basic criterion when developing a protection project. Its meaning is that with minimal use of funds and protection measures to ensure the requirements for electromagnetic compatibility, functional and information security of electronic network systems in the conditions of the expected impact $[21,22,27]$.

The development of protection measures against the effects of damaging factors depends on [15]:

- the intensity of lightning strikes in the appropriate place;

- the estimation of the level of vulnerability of the object itself, for example, underground power supply systems are considered less vulnerable than aerial ones;

- the cost of equipment connected to the protected electrical installation, as this can be an important criterion for complicating the protection scheme and vice versa.

From the economic point of view, the optimal solution to ensure the reliability of lightning protection of the objects is the zonal concept of protection [15].

A hybrid telecommunications network meets this requirement by proposing the separation of communication channels by transmission media. The selection of network segments by the nature of the transmitted signal avoids the action of such direct lightning strikes and secondary effect of lightning activity that do not physically affect them [28].

The conducted study is a continuation, firstly, of the International Telecommunication Union's research of identifying threats to the telecommunications network inherent in global warming, including lightning, and secondly, to identify measures to protect against threats. Future research should continue to investigate possible threats from other natural disasters, acting on their bias. This will prevent emergencies, particularly in the field of telecommunications.

\section{CONCLUSIONS}

1. The result of the conducted study is the detection of at least 11 DFs of direct lightning strike and secondary effect of lightning activity. Appropriate measures have been developed and used to counteract the destructive effects of 6 of the damaging factors. Exposing the 5 subtle effects of the damaging factors of lightning requires countermeasures. Under conditions of transformation of the natural-anthropogenic system, they can cause unexpected results. Possible precautionary measures to reduce losses are developed according to the generalized scheme of application of response measures.

2. Measures of protection of the objects of the telecommunications network from lightning have been systematized. The generalized scheme is universal and is suitable for application in the development of lightning protection of arbitrary objects from arbitrary damaging factors. The scheme includes short-term hazard prognostication and warning, lightning-fast construction. Long-term measures include the use of lightning-resistant materials and structures, lightning protection systems, reconfiguration of the telecommunications system. 
3. According to the generalized scheme of application of the measures on lightning protection of the objects of a telecommunications network, the hybrid telecommunications network can be the optimum decision on protection. It meets the requirements by proposing the separation of communication channels by transmission media. The selection of network segments by the nature of the transmitted signal avoids the action of such direct lightning strike and secondary effect of lightning activity, which do not physically affect them.

\section{REFERENCES}

1. D. M. Romps, J. T. Seeley, D. Vollaro et al. Projected increase in lightning strikes in the United States due to global warming, Science, Vol. 346 (6211), pp. 851-854, November 2014.

2. D. L. Finney, R. M. Doherty, O. Wild et al. A projected decrease in lightning under climate change, Nature Climate Change, Vol. 8, pp. 210-213, February 2018.

3. P. G. Neumann.Risks to the Public in the Use of Computer Systems and Related Technology, SRI International, California, 2011.

4. Final Report on the August 14, 2003 Blackout in the United States and Canada: Causes and Recommendations, U.S.-Canada Power System Outage Task Force, 2004.

5. C. J. Schultz, N. J. Nauslar, J. B. Wachter et al. Spatial, Temporal and Electrical Characteristics of Lightning in Reported Lightning-Initiated Wildfire Events, Fire, Vol. 2 (2), 15 p., March 2019.

6. J. I. Chang and C.-C. Lin.A study of storage tank accidents, Journal of Loss Prevention in the Process Industries, Vol. 19 (1), pp. 51-59, January 2006.

7. P. Thurber et al. AD-A175 865 Historic properties report: Picatinny Arsenal. Final report, U.S. Department of the Interior, 1985.

8. E. V. Ivanov, V. M. Lobojchenko, S. R. Artem'ev et al. Emergency situations with explosions of ammunition: patterns of occurrence and progress, Eastern-European Journal of Enterprise Technologies, Vol. 1/10 (79), pp. 26-35, February 2016.

9. Je. M. Bazeljan\& Ju. P. Rajzer.Physics of lightning and lightning protection, Fizmatlit, Moscow, 2001.

10. M. M. Kozak.Linear communication structures, Vinnytsia Higher Vocational School, 2009.

11. D. Sunde.Lightning protection of buried toll cables, The Bell system Technical Journal, Vol. 24 (2), pp. 253-300, December 1945.

12. K. V. Huda and O. S. Ostrogradska.Spatial and temporal distribution features of thunderstorms on the territory of Ukraine and their forecasting: the current state of the issue and development prospects, Hidrolohiia, hidrokhimiiaihidroekolohiia, Vol. 3, pp. 105-112, September 2017.

13. A. Mostajabi, D. L. Finney, M. Rubinstein et al. Nowcasting lightning occurrence from commonly available meteorological parameters using machine learning techniques, npj Climate and Atmospheric Science, Vol. 2 (1), pp. 41-56, November 2019.

14. V. Danylovych\& V. Smychok.Forecasting lightning's dangerous of the phenomena on the basis of likelihood models of process of passive registration and lightning direction finding, Electrical engineering, Is. 60, pp. 78-83, December 2009.

15. Analysis of modern foreign and domestic experience in installing lightning protection systems for electrical networks, Research and Design Center for the Development of the United Energy System of Ukraine NPC "Ukrenergo", 2018.

16. State standard of Ukraine B V.2.5-38:2008. Lightning protection of buildings and structures (IEC 92305:2006, NEQ).

17. A. A. Vlasov.Active lightning protection: principle of operation, analysis of efficiency in comparison with passive lightning protection, Belarusian National Technical University, Minsk, 2018.

18. Active lightning protection, available at: https://www.amnis.ru/activnaya-molniezashita/obzor-sta tei-mirovogo-soobshestva.php.

19. G. M. Gunjaev, L. V. Chursova, A. E. Raskutin et al. Lightning resistance of modern polymer composites, Aviacionnyematerialyitehnologii, Vol. 2, pp. 36-43, December 2012.

20. IEC 62305-4:2010. Protection against lightning - Part 4: Electrical and electronic systems within structures.

21. IEC 62305-1:2010. Protection against lightning - Part 1: General principles.

22. IEC 62305-2:2012 Protection against lightning - Part 2: Risk management.

23. IEC 62305-3:2012 Protection against lightning - Part 3: Physical damage to structures and life hazard.

24. ITU-D Study Group 2. Question 6/2: ICT and climate change. Final Report, ITU, 2017.

25. ITU-T Recommendation K.47 (05/2012). Protection of telecommunication lines using metallic conductors against direct lightning discharges.

26. Recommendation ITU-R P.1817-1 (02/2012). Propagation data required for the design of terrestrial free-space optical links.

27. B. B. Akbashev, N. V. Baljuk\& L. N. Kechiev.Protection of telecommunications objects from electromagnetic influences, Grifon, Moscow, 2014.

28. P. Anakhov, V. Zhebka, G. Grynkevych\& A. Makarenko.Protection of telecommunication network from natural hazards of global warming, Eastern-European Journal of Enterprise Technologies, Vol. 3/10 (105), pp. 28-37, June 2020.

29. State standard of the Russian Federation 22.0.06-95. Safety in emergencies. The sources of natural emergencies. Injuring factors. Nomenclature of parameters of injuring influences.

30. V. G. Sajko, L. V. Dakova, O. V. Dikarev et al. Determination of the optimal parameters of signals with high noise immunity for FH-OFDMA cognitive radio networks, Telecommunication and information technologies, No. 3, pp. 34-44, September 2016. 
31. V. P. Majdanjuk.Encryption and protection of information,Vinnytsia National Technical University, 2009.

32. S. A. Sokolov.Potential risk of incorrect reception of information via optical cable during lightning discharges, Naukoemkietehnologii v kosmicheskihissledovanijahZemli, Vol. 3, pp. 22-25, June 2014.

33. D. A. Baron.Trunk and intra-zone cable communication lines. Linear structures, Radio isvjaz', Moscow, 1988.

34. A. A. Sinkevich \& T. V. Kraus.Cloud seeding in Saudi Arabia and statistical assessment of the results, Meteorologija i gidrologija, Vol, 6, pp. 26-37, June 2010.

35. B. P. Koloskov, V. P. Korneev, V. V. Petrov et al. The modern concept of meteorological protection of megacities by methods of active impact, Meteorologija i gidrologija, Vol. 8, pp. 21-32, August 2010.

36. Convention on the Prohibition of Military or any other Hostile Use of Environmental Modification Techniques (Adopted by Resolution 31/72 of the United Nations General Assembly on 10 December 1976). Official Records of the General Assembly, Thirty-first Session. Supplement No. 39 (A/31/39), pp. 37-38.

37. E. R. Smidt.Lightning Analysis in a High-voltage Transmission Environment, Vaisala Tucson USA, 2003.

38. A. V. Ospina, D. Faulkner, K. Dickerson et al. Resilient pathways: the adaptation of the ICT sector to climate change, ITU, 2014.

39. A. D. M. Africa \& F. M. Dimaala. Enhanced Traffic Scheduling Algorithm by Implementing Committed Information Rate (CIR) in Broadband Systems for a Disaster-stricken Footprint in Telecommunications, International Journal of Advanced Trends in Computer Science and Engineering, Vol. 9, no. 4, pp. 4209-4215, August 2020.

40. S. Sairohith, N. K. B. Venkatesh, J. K. R. Sastry \& J. Rajasekhar. Inter-Networking Heterogeneous Embedded Networks through Universal Bus, International Journal of Advanced Trends in Computer Science and Engineering, Vol. 9, no. 2, pp. 1430-1439, March-April 2020.

41. N. Harum, W. Md Shah, N. Haniza, N. A. Zakaria \& Z. Z. Abidin. Performance Evaluation on Single-Input Single-Output and Multiple-Input Single-Output Technique in Visible Light Communication, International Journal of Advanced Trends in Computer Science and Engineering, Vol. 9, no. 4, pp. 5680-5685, July-Augusr2020.

42. M. I. Stjebljuk.Civil defense and civil protection,Znannja, Kyiv, 2013.

43. A. S. Tolstyh.Civil Protection, Donetsk national university of economics and trade named after MykhailoTugan-Baranovsky, 2012.

44. A. V. Agafonov, A. V. Oginov\& K. V. Shpakov.Prebreakdown phase in atmospheric discharges, Physics of Particles and Nuclei Letters, Vol. 9 (4-5), pp. 380-383, August 2012.
45. S. A. Sokolov.Physical processes in a thundercloud, and their impact on the optical line, T-Comm, Vol. 8, pp. 135-137, August 2013.

46. I. M. Vikulin, Sh. D. Kurmashev, V. E. Gorbachov\& S. K. Kryskiv.Degradation of the elements of the optical communication under irradiation, Scientific works of the Odessa National Academy of Communications named after A. S. Popov, No. 1, pp. 57-63, June 2012. 